Jurnal Ilmu Budaya, Vol. 18, No. 2 Februari Tahun 2022

\title{
ANALISIS BENTUK FUNGSI DAN MAKNA WACANA CORONA VIRUS VERSIBAHASA INGGRIS (SUATU TINJAUAN PRAGMATIK)
}

\author{
Edward $^{1}$, Sorta Hutahaean ${ }^{2}$ \\ Universitas Lancang Kuning \\ edwards07@unilak.ac.id ${ }^{1}$,sortahutahaean@unilak.ac.id ${ }^{2}$
}

This research was aimed at describing types of forms and meanings found in documentarytext of the current cyber paper on corona virus. The result shows that texts tend to be representative, and out of 32 data, only one was in the form of declarative, three directives, four commissives, and the rests were representatives. Meaning and form were determined by context and co-text. It can be concluded that the meaning is context-dependent but the structure varies accordingly. Some may have compound, comples, compound complex and even transformative sentences. In short, the context influences the whole text. It was found that exospheric context or reference was greatly influencing the meaning of the text.

Keywords: discourse, type, meaning and function

\section{A. PENDAHULUAN}

Bahasa adalah alat komunikasi yang dipergunakan oleh semua orang dalam kehidupan sehari-hari. Tanpa menggunakan bahasa seseorang tidak akan dapat bersosialisasi, bahkan mungkin juga tidak akan dapat memenuhi kebutuhan hidupnya. Seseorang pada umumnya tidak peka terhadap perkataan atau kalimatkalimat yang digunakan dalam suatu percakapan bahkan mungkin tidak menyadari makna dari frasa, klausa atau kalimat yang dituturkan serta jenis tuturan yang seharusnya dipergunakan, baik di lingkungan instansi, maupun di lingkungan masyarakat pada umumnya. Hal ini dapat terjadi karena beberapa faktor, diantaranya faktor pengetahuan, faktor usia dan pendidikan, jenis kelamin, lingkungan, pergaulan, situasi dan 
Jurnal Ilmu Budaya, Vol. 18, No. 2 Februari Tahun 2022

keadaan, internal dan eksternal dan berbagai faktor lainnya. Sebagai salah satu contoh, petuturan yang disampaikan seorang lelaki pastilah berbeda dengan petuturan yang disampaikan oleh seorang wanita. Selanjutnya, dalam menyampaikan tuturan, seseorang tentu seharusnya menyesuaikan ujaran- ujarannya dengan etika dan bentuk percakapannya karena representasi suatu kalimat dapat merefleksikan siapa dan bagaimana penuturnya. Kajian yang mempersoalkan tentang tuturan-tuturan ini merupakan suatu kajian di bidang pragmatik.

Linguistik sebagai cabang ilmu kajian bahasa memiliki berbagai cabang. Cabang-cabang itu di antaranya adalah fonologi, morfologi, sintaksis, pragmatik, dan sebagainya. Di antara cabang tersebut memiliki hubungan yang menelaah tentang makna-makna satuan lingual yaitu semantik dan pragmatik. Hal ini didukung oleh Wijaya (2006: 2) yang berpendapat bahwa semantik mempelakari makna secara internal, sedangkan pragmatik mempelajari makna secara eksternal. Bertolak dari pendapat Leech (dalam Wijaya, 1996:4), yaitu kehadiran pragmatik hanyalah tahap terakhir dari perkembangan linguistik yang berangsur-angsur, mulai dari disiplin ilmu yang mengenai data fisik tuturan menjadi disiplin ilmu yang sangat luas bersangkutan dengan bentuk, makna, dan konteks.

Bidang "pragmatik" dalam linguistik dewasa ini mulai mendapat perhatian para peneliti dan pakar bahasa di Indonesia. Bidang ini cenderung mengkaji fungsi ujaran atau fungsi bahasa dari pada bentuk atau strukturnya. Hal itu sesuai dengan pengertian pragmatik yang dikemukakan oleh Levinson (1987: 5 dan 7), pragmatik adalah kajian bahasa dalam penggunaannya atau kajian bahasa dan perspektif fungsional. Artinya, kajian ini mencoba menjelaskan aspek struktur bahasa dengan mengacu ke pengaruh atau sebab-sebab yang menentukan makna ujaran dari sisi fungsi. Levinson (dalam Tarigan, 2009: 31) melanjutkan bahwa definisi pragmatic lebih detail, 
Jurnal Ilmu Budaya, Vol. 18, No. 2 Februari Tahun 2022

yaitu telaah mengenai relasi antara bahasa dan konteks yang merupakan dasar bagi suatu catatan atau laporan pemahaman bahasa, dengan kata lain telaah mengenai kemampuan pemakaian bahasa menghubungkan serta penyerasian kalimat-kalimat dan konteks secara tepat.

Dapat ditarik simpulan berdasarkan pada pandanganpandangan yang memaparkan bahwa pragmatik adalah bidang linguistik yang mengkaji telaah tuturan bahasa dari segi makna. Sejalan dengan pendapat di atas, pragmatik mengkaji tentang tuturan bahasa. Dengan demikian pragmatic sangat erat dengan tindak tutur. Tuturan tersebut memiliki makna, maksud, atau tujuan, sehingga perlu dikaji dengan bidang pragmatik.

Berkenaan dengan tindak tutur, Searle (dalam Leech, 2011: 163-166) berpendapat membagi tindak tutur ilokusi berdasarkan berbagai kriteria, yaitu asertif, direktif, komisif, ekspresif, dan deklaratif. Berikut pemaparannya: (a) Asertif, tindak tutur yang terikat akan keberadaan proposisi yang dituturkan, seperti menyatakan, mengusulkan, membuat, mengeluh, mengemukakan pendapat, melaporkan; (b) Direktir, tidak tutur yang menghasilkan suatu efek yang dituturkan oleh penutur, seperti memesan, memerintah, memohon, menuntut, memberi nasihat.; (c) Komisif, tidak tutur yang terikat pada tindakan di masa yang akan datang, seperti menjanjikan, menawarkan, berkaul; (d) Ekspresif, tindak tutur tersebut terikat akan suatu tuturan yang mengutarakan sikap psikologis secara tersirat, seperti, mengucapkan terima kasih, mengucapkan selamat, memberi maaf, mengecam, memuji, mengucapkan belasungkawa, dan sebagainya; (e) Deklaratif, tindak tutur tersebut merupakan tindak tutur yang terikat akan misi proposisi dengan keadaan aslinya, benar atau salah, seperti mengundurkan diri, membaptis, memecat, memberi nama, menjatuhkan hukuman, mengucilkan/membuang, mengangkat (pegawai), dan sebagainya.

Penelitian ini penting untuk dilakukan mengingat fitur kebahasaan tidak hanya dapat ditinjau dari sisi 
Jurnal Ilmu Budaya, Vol. 18, No. 2 Februari Tahun 2022

bentuk, fungsi dan makna, tetapi juga dari sisi makro, yakni referensi internal dan eksternal yang meninjau bagaimana kesinambungan makna dan maksud dari suatu teks wacana baik tulis, maupun lisan. Maka kajian ini akan menjawab masalah, yaitu (1) Apa bentuk ujaran yang dituturkan dalam wacana yang memuat corona virus? (2) Apa fungsi dan makna teks dalam pemberitaan corona virus?

\section{B. METODE PENELITIAN}

Data dalam penelitian ini bersifat dokumentasi. Data yang didokumentasi adalah data yang dipublikasikan oleh website official dari kemenkes. Penelitian ini dilakukan dengan metode ilmiah dengan dasar perkembangan serta kerangka kerja logika dalam dunia ilmu pengetahuan dengan menggunakan metode deskriptif kualitatif seperti yang dikemukakan oleh Djadjasudarma (1993:10) yang menyatakan bahwa penelitian kualitatif merupakan prosedur penelitian yang menghasilkan data deskriptif berupa data lisan ataupun data tertulis. Selanjutnya, metode ini berupaya memberikan deskripsi yang bersifat sistematis, faktual dan akurat mengenai data, sifat- sifat serta hubungan fenomena-fenomena yang diteliti sehingga akan didapatkan gambaran data secara ilmiah

Analisis data akan dilakukan dengan mengikuti alur metode padan dan metode agih; metode padan dengan teknik pilah unsur dan metode agih dengan teknik bagi unsur langsung

(Sudaryanto, 1993). Seluruh data akan dipilah dan setelah pemilahan dilakukan, peneliti menerapkan metode agih untuk melihat unsur lingual. Kemudian, data yang telah terkumpul dan terkelompok akan diuraikan dengan menggunakan alur metode kualitatif dengan pengertian bahwa setiap langkah analisis dilakukan sesuai dengan penelusuran identifikasi klasifikasi, fungsi ujaran dan kecenderungan ujaran yang digunakan.

Metode penyajian hasil analisis 
Jurnal Ilmu Budaya, Vol. 18, No. 2 Februari Tahun 2022

data dalam penelitian ini menggunakan metode informal dan formal (Sudaryanto, 1993:145). Adapun metode penyajian informal berupa perumusan dengan penggunaan katakata, sedangkan metode penyajian formal berupa perumusan dengan tanda, dan lambang, seperti tanda tambah, kurung, titik dua, titik koma, tanda tanya, tanda panah, kurung biasa, kurung kurawal, huruf sebagai singkatan nama, dan sebagainya.

\section{HASIL DAN PEMBAHASAN}

Teks pemberitaan corona virus yang dirilis pada tanggal 9 Maret 2021 (data pada table I) bersifat informatif deskriptif dengan judul berita "Indonesia receives first shipment of 1.1 million COVID-19 vaccines doses through COVAX" [Indonesia menerima pengiriman pertama vaksin COVID 19 sebanyak 1,1 juta dosis melalui COVAX].

Terdapat 28 butir (kalimat) dalam pemberitaan yang dirilis. Teks wacana cukup unik karena teks dikemas dalam frasa yang panjang sehingga dalam satu ujaran bisa terdapat lebih dari satu struktur bentuk seperti terlihat (6), (10), (20), dan (26) table 1. Hal ini menunjukkan bahwa meskipun wacana bersifat informatif atau berita tidak berarti bahwa semua teks bercorak sama. Kedinamisan struktur bentuk dikemas dalam konteks yang membangun teks, dan tentunya mengemban makna kontektual pula. Dari kelima struktur bentuk, yakni representative, commisive, directive, declarative dan expressive hanya struktur bentuk ekspressive saja yang tidak ditemukan.

Dari data yang diperoleh terdapat 24 bentuk struktur representative, 4 commisive, 3 directive dan 1 declarative. Bentuk struktur teks yang sama dapat memiliki makna yang berbeda. Bentuk representative menjadi ciri karena wacana teks merupakan pemberitaan tentang alokasi vaksinasi sebagai tindakan preventif terhadap ancaman covid 19. 
Jurnal Ilmu Budaya, Vol. 18, No. 2 Februari Tahun 2022

Tabel 1: Distribusi Struktur Bentuk dan Fungsi

\begin{tabular}{|c|c|c|c|}
\hline N0 & $\mathrm{Uj}$ aran & Struktur Bentuk & Fung i i \\
\hline 1 & $\begin{array}{l}\text { Indonesia received } 1,113,600 \text { doses of the } \\
\text { AstraZeneca vaccine today as the first } \\
\text { shipment of the 11,704,800 doses allocated to } \\
\text { Indonesia under the COVAX Facility until } \\
\text { May. }\end{array}$ & representative & Informing \\
\hline 2 & $\begin{array}{l}\text { The COVID-19 vaccine doses, which were } \\
\text { sent from AstraZeneca's hub in Amsterdam, } \\
\text { arrived at Soekarno Hatta International } \\
\text { Airport in Jakarta this evening }\end{array}$ & representative & Telling \\
\hline 3 & $\begin{array}{l}\text { Subsequent allocations of doses to Indonesia } \\
\text { through COVAX are expected to be } \\
\text { announced in the coming weeks for the } \\
\text { second half of the year. }\end{array}$ & commisive & promising \\
\hline 4 & $\begin{array}{l}\text { Indonesia's Minister of Health and Minister } \\
\text { of Foreign Affairs were present to receive the } \\
\text { shipment, along with COVAX partners }\end{array}$ & representative & Telling \\
\hline 5 & $\begin{array}{l}\text { COVAX is co-led by Gavi, the Vaccine } \\
\text { Alliance, the World Health Organization } \\
\text { (WHO) and the Coalition for Epidemic } \\
\text { Preparedness Innovations (CEPI), with } \\
\text { UNICEF as a key implementing partner. }\end{array}$ & representative & Informing \\
\hline 6 & $\begin{array}{l}\text { The doses received today through COVAX } \\
\text { are intended to protect priority groups in the } \\
\text { country, and distribution will be made in line } \\
\text { with the prioritization criteria outlined in } \\
\text { Indonesia's National Deployment } \\
\text { Vaccination Plan. }\end{array}$ & $\begin{array}{l}\text { Representative } \\
\text { Commisive }\end{array}$ & $\begin{array}{l}\text { Informing } \\
\text { Promising }\end{array}$ \\
\hline 7 & $\begin{array}{l}\text { "The arrival of vaccines allocated by } \\
\text { COVAX Facility demonstrates global } \\
\text { solidarity and reignites hope in ending the } \\
\text { pandemic. }\end{array}$ & representative & Telling \\
\hline 8 & $\begin{array}{l}\text { We have a lot of work to do to achieve a safe } \\
\text { and smooth vaccination rollout across } \\
\text { Indonesia }\end{array}$ & Directive & Commanding \\
\hline 9 & The time for health equity is now. & Declarative & Declaring \\
\hline 10 & $\begin{array}{l}\text { We need to ensure that these vaccines reach } \\
\text { everyone that needs it and that no one is left } \\
\text { behind," said WHO Representative Dr N. } \\
\text { Paranietharan. }\end{array}$ & Directive directive & $\begin{array}{l}\text { Ordering } \\
\text { Commanding }\end{array}$ \\
\hline 11 & $\begin{array}{l}\text { Today's shipment is a historic step in what } \\
\text { will be the largest global vaccine } \\
\text { procurement and supply operation in history. }\end{array}$ & representative & Telling \\
\hline
\end{tabular}


Jurnal Ilmu Budaya, Vol. 18, No. 2 Februari Tahun 2022

\begin{tabular}{|c|c|c|c|}
\hline 12 & $\begin{array}{l}\text { COVAX's overall ambition by the end of } \\
2021 \text { is to procure and supply } 2 \text { billion } \\
\text { vaccines to all countries participating in the } \\
\text { COVAX Facility. }\end{array}$ & representative & Telling \\
\hline 13 & $\begin{array}{l}\text { The COVAX Facility aims to secure enough } \\
\text { vaccines for } 20 \text { per cent of the population of } \\
\text { every participating country, in order to help } \\
\text { reduce mortality rates, protect health systems } \\
\text { and resume critical services }\end{array}$ & representative & Telling \\
\hline 14 & $\begin{array}{l}\text { Low-and lower-middle income countries that } \\
\text { have enrolled in the Advance Market } \\
\text { Commitment of the COVAX Facility do not } \\
\text { pay for the } 20 \text { per cent of the doses they } \\
\text { receive. }\end{array}$ & representative & telling \\
\hline 15 & $\begin{array}{l}\text { "The delivery of these vaccines is a critical } \\
\text { step toward ending the COVID-19 } \\
\text { pandemic," said UNICEF Representative } \\
\text { Debora Comini }\end{array}$ & representative & Telling \\
\hline 16 & $\begin{array}{l}\text { "With every round of vaccination, a return } \\
\text { tonormalcy becomes a stronger reality. }\end{array}$ & representative & Telling \\
\hline 17 & $\begin{array}{l}\text { With every vaccine dose, more people are } \\
\text { protected. }\end{array}$ & representative & Telling \\
\hline 18 & $\begin{array}{l}\text { With every teacher vaccinated, more children } \\
\text { have the potential to return to school." }\end{array}$ & representative & Telling \\
\hline 19 & $\begin{array}{l}\text { For several months, COVAX partners have } \\
\text { been supporting governments and partners } \\
\text { around the world in readiness efforts to } \\
\text { prepare for this moment }\end{array}$ & representative & informing \\
\hline 20 & $\begin{array}{l}\text { In Indonesia, UNICEF, WHO and other } \\
\text { partners have provided technical assistance } \\
\text { to strengthen Indonesia's cold and supply } \\
\text { chains so that the country has adequate } \\
\text { infrastructure to transport and store the } \\
\text { vaccines for delivery. }\end{array}$ & $\begin{array}{l}\text { Representative } \\
\text { Representative }\end{array}$ & Telling Telling \\
\hline 21 & $\begin{array}{l}\text { They have also built the capacities of health } \\
\text { workers and worked with communities in } \\
\text { addressing misinformation and increasing } \\
\text { acceptance of safe vaccines. }\end{array}$ & representative & Telling \\
\hline
\end{tabular}


Jurnal Ilmu Budaya, Vol. 18, No. 2 Februari Tahun 2022

\begin{tabular}{|c|c|c|c|}
\hline 22 & $\begin{array}{l}\text { "Today's delivery marks an important } \\
\text { milestone for Indonesia, not just in terms of } \\
\text { the fightback against COVID-19, but in the } \\
\text { wider effort to restore the country's health by } \\
\text { helping routine immunizations against other } \\
\text { killer diseases - an area where the country } \\
\text { has made so much progress in recent years- } \\
\text { get back on track," said Sam Muller, Head of } \\
\text { Country Engagement at Gavi, the Vaccine } \\
\text { Alliance. }\end{array}$ & representative & Informing \\
\hline 23 & $\begin{array}{l}\text { Gary Quinlan, Australian Ambassador } \\
\text { toIndonesia welcomed the arrival of COVAX } \\
\text { AMC doses }\end{array}$ & representative & Telling \\
\hline 24 & $\begin{array}{l}\text { Mr Quinlan said: "There is no higher } \\
\text { priority for our region than access to safe } \\
\text { and effective COVID-19 vaccines, which will } \\
\text { help Indonesia and the region reopen and } \\
\text { recover." }\end{array}$ & representative & Telling \\
\hline 25 & $\begin{array}{l}\text { "Today the Indonesian people are receiving } \\
\text { a first quota of around } 1 \text { million doses under } \\
\text { the COVAX Facility to cover the most urgent } \\
\text { needs. Throughout } 2021 \text { and will support } \\
\text { Indonesia in its fight against COVID } 19 .\end{array}$ & representative & Informing \\
\hline 27 & $\begin{array}{l}\text { Team Europe - comprising the EU, its } \\
\text { Member States and its financial institutions - } \\
\text { is proud to be a lead contributor to the } \\
\text { COVAX Facility with } € 2.2 \text { billion (IDR } 38 \\
\text { trillion) so far. }\end{array}$ & representative & Telling \\
\hline 2 & $\begin{array}{l}\text { COVAX is a success story of solidarity and } \\
\text { multilateralism, of working together to solve } \\
\text { the biggest global challenge we face" said } \\
\text { EU Ambassador to Indonesia Vincent Piket. }\end{array}$ & representative & Telling \\
\hline
\end{tabular}

\section{Pembahasan}

Teks wacana berisikan informasi tentang penanganan ancaman covid 19 yang disampaikan oleh orang yang berwewenang. Teks dipadu dalam konteks yang berkesinambungan karena virus tersebut telah menjadi pandemi atau mengglobal.
Kalimat=kalimat pada wacana bervariasi, dan jika ditinjau dari hubungan sintaksis jenisnya cenderung compound, complex, compound complex bahkan ada juga bentuk kalimat transformasi adjektiva. Itu sebabnya dalam satu ujaran bisa terdapat lebih dari satu struktur bentuk 
Jurnal Ilmu Budaya, Vol. 18, No. 2 Februari Tahun 2022

seperti dijumpai pada (6) The doses received today through COVAX are intended to protect priority groups in the country, and distribution will be made in line with the prioritization criteria outlined in Indonesia's National Deployment Vaccination Plan. [Dosis yang diterima hari ini melalui COVAX ditujukan untuk melindungi kelompok prioritas, dan distribusi akan dilakukan sesuai dengan kriteria prioritas yang diuraikan dalam Rencana Vaksinasi Nasional Indonesia]. Fungsi pada frasa pertama "The doses received today through COVAX are intended to protect priority groups in the country,...."

Adalah

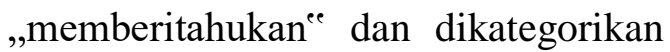
sebagai bentuk representative, sementara pada frasa berikutnya "... and distribution will be made in line with the prioritization criteria outlined in Indonesia's National Deployment Vaccination Plan". di mana fungsi teksnya berubah menjadi „menjanjikan sehingga bentuk juga berubah menjadi commisive. Dari data ini dapat dikatakan bahwa bentuk-bentuk ujaran dapat memiliki maksim kesesuaian, yakni, bentuk representative bisa padu dengan commisive. Kasus seperti ini juga juga terdapat pada (10), (20), dan (26).

\section{E. SIMPULAN DAN SARAN}

Dari hasil dan pembahasan di atas dapat disimpulkan bahwa teks wacana corona virus narasi memiliki cirri di mana bentuk strukturnya cenderung representative. Dari 32 data ditemukan 24 struktur representative, 4 commisive, 3 directive dan 1 declarative. Bentuk struktur teks yang sama dapat memiliki makna yang berbeda karena bisa terdapat dua atau lebih struktur dengan makna kontekstual yang mengikatnya. Jadi, terdapat maksim kesepakatan teks dan co=teks dalam konteknya. Bentuk representative menjadi ciri karena wacana teks merupakan pemberitaan tentang alokasi vaksinasi sebagai tindakan preventif terhadap ancaman covid 19. Namun, terdapat juga satu bentuk declarative yang unik karena 
Jurnal Ilmu Budaya, Vol. 18, No. 2 Februari Tahun 2022

bersifat implisit dengan pengertian

makna harus dipahami melalui konteks situasional yang menjadi basis ujarannya.

Penelitian ini perlu ditindaklanjuti agar dapat lebih memahami atau menerapkan konsep dan aplikasi wacana pragmatik secara mendalam karena banyak implikasi yang harus atau dapat digali sehingga kajian wacana pragmatik lebih kaya.

\section{DAFTAR PUSTAKA}

Allen, K. 1996. Linguistic Meaning Vol.1\&2. London: Routledge \& Kegan Paul.

Austin, J. L. 1969. Performative Contantive, an Essay in Philosophy of Language. Cambridge: Cambridge University Press.

Chaer, A. 1994. Linguistik Umum. Jakarta: Rhineka.

Cutting, Joan. 2002. Pragmatics and Discourse. London: Routledge.

Flick, Uwe, Kardorff, Ernst Von, Steinke, Ines. 2000. A Companion to Qualitative Research. London: Sage.

Griffiths, Patrick. 2006. An
Introduction to English Semantics and Pragmatics. England: Edinburgh University Press.

Horn, Laurence R; Ward, Gregory. 2006. The Handbook of Pragmatics. United Kingdom: Blackwell.

Miles, Matthew B. \& A. Michael Huberman. 1994. Qualitative Data Analysis: An Expanded Sourcebook. London: SAGE Publications

Moleong, J.L. 2000. Metodologi Penelitian Kualitatif. Bandung: PT. Remaja Rosdakarya.

Sudaryanto. 1993. Metode dan Aneka Teknik Analisis Bahasa. Jakarta. Duta Wacana University Press. 